\title{
The Trofobiose Theory and organic agriculture: the active mobilization of nutrients and the use of rock powder as a tool for sustainability
}

\author{
WAGNER L. POLITO \\ Instituto de Química de São Carlos, USP, Caixa Postal 780, 13560-970 São Carlos, SP, Brasil \\ Manuscript received on September 29, 2005; accepted for publication on March 13, 2006; \\ presented by OTHON H. LEONARDOS
}

\begin{abstract}
The primary objective of the present paper is to link some relevant concepts on the use of ecological agricultural practices to the production of food crops. In a special topic the Trofobiose Theory, as well as the principle of Active Dissolution of Rocks are considered as important tools in improving the sustainability of Organic, Biodynamic and Process Agricultures.
\end{abstract}

Key words: sustainability, trofobiose, vegetal nutrition, nutritional equilibrium, agro-ecology, rock powders, mineral fertilizations, organic fertilization.

\section{INTRODUCTION}

\section{DEFINITIONS AND TERMINILOGY}

\section{Product agriculture}

This type of agriculture is based only on calendar and product without any conditions imposed on the process domain. Product agriculture makes extensive use of soluble inorganic nutrients to replenish soil fertility and toxic substances to control plagues and diseases.

\section{Process agriculture}

Process agriculture is based on the application of the so called "correct" agricultural processes involving orderly ecological procedures and techniques aimed at minimizing the use of soluble inorganic nutrients to replenish soil fertility. It also focuses on the soil/plant equilibrium and employs alternative or even substitutive procedures to reduce the use

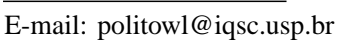

of toxic substances in controlling plagues, diseases and viruses.

\section{Organic and biodynamic agricultures}

Both of these types of agricultural practices are founded on the treatment of the soil/plant system as an organism with life that must be preserved by improving biological inputs in order to obtain pure and well poised foodstuff for human or animal consumption necessary for sustainability. Practices based on organic and biodynamic agricultures impose severe restrictions on the use of soluble inorganic nutrients and strongly recommend low solubility agrominerals and organic inputs - manures, plant/tree pruning leguminous mulches, and stabilized solid organic residues derived from the biological decomposition of bovines and sugar cane residues to insure the replenishment of soil fertility, soil/plant equilibrium and specially the effects of symbiosis between soil microorganism and the rizosphere. 
Preliminary Topics: SOME COMMENTS, PAPERS AND NOTICES

\section{The China Food CHALLENGE}

During the last decade, the Chinese government encouraged its farmers to migrate from traditional agricultural cultures especially rice to legumes and fruits cultivation which are more lucrative and present a better return on investment. Following this advice, a vast area of over 13 millions hectares, equivalent to the area of England, was converted to a huge horticultural and fruit production zone. However, the consequences of such drastic changes became apparent only years later. Five years after the change, the soil suffered drastic alterations and became sterilized due to an increase in soil acidity, the nitrogen content increased fourfold while the phosphorous content doubled. The result was the death of, microorganisms, especially bacteria, which help in plant growth. These microorganisms almost disappeared from the soil resulting in some plants showing deformed products. These facts were reported in international papers such as “Environmental Geochemistry and Health" and New Scientist. The overall breakdown of food production was more than $20 \%$ on grains - rice and corn with serious consequences on food supply to more than 1.2 million inhabitants. Agricultural researchers in the western hemisphere, after investigating the causes of these soil problems, concluded that no problem existed with the production of fruit and legumes. According to their findings, the real cause of the observed disequilibrium was thought to be the excessive use of soluble fertilizers which endangered the natural source of potable water. It is important to remark that the overall agricultural production of China is equivalent to twice that of the United States. However, China employs four times more fertilizer than the US (Ciência e Tecnologia do Brasil - Pesquisa FAPESP, $\mathbf{N}^{\circ} 105$, November, 2004).

\section{FungI DiseASE ON COCOA}

Recently, Scarpari et al. 2005 reported their research findings on a fungi disease caused by Crini- pelli perniciosa which is known to cause severe devastation of cocoa. Scarpari et al. pointed out some details on hormonal disequilibrium and the extra doses of nutrients as well as some others chemicals defenses (liberation of 10 times more alkaloids - theobromine and caffeine as natural sources of defense against this fungi disease then followed by the degradation of protein and the beginning of apoptosis - the programmatic death of vegetal tissues as a means of isolating the infected tissues.

\section{COMMENTS}

The abovementioned facts and findings give clear evidences of nutritional disequilibrium and explain how plants acquire fragilities and defenses against diseases through trophic effects. They also explain how nutritional problems in plants can have serious consequences on food supply and how the Trofobiose Theory can help us understand nutritional equilibrium thus improving tools necessary to obtain better food crops based on agro ecological practices.

\section{The Trofobiose Theory}

The term Trofobiose comes from the Greek: Trofo (Aliment) and Biose (Existence of Life). According to this Theory, all vegetal organisms, food crop inclusive, become vulnerable to plague infestation (insects, acaroids) and diseases (fungi, bacterial infections and other diseases) when excess free amino-acids and glycosides reductor species are present in their metabolic system, a source of system disequilibrium which gives rise to a condition of proteolysis. On proteolysis, a set of protein hydrolysis reactions takes place with the subsequent storage of proteolysis products in cellular vacuoles (free amino-acid and glycosides reductor species). Any external interference on the metabolic system capable of stimulating this proteins synthesis, be it of - genetic, physiologic, climatic order or due to the type of agricultural procedures employed, can generate entomologic and phytopatologic resistances of the vegetal organism.

The Trofobiose Theory was first introduced by Chaboussou in the 1980s. His book on the subject provided a series of concepts on the agro-ecol- 
ogical approach to agricultural practices but however, without any parallelism made with respect to the ideas published by Steiner (originally published in 1924 and after in 1993) who, before then, had focused mainly on the principles of Organic and Biodynamic Agricultural Approaches.

Basically, Chaboussou's theory was developed based on recursive methods cited in literature, and among his postulates, his text in which he gave several definitions and his terminology - or general glossary - emphasized, according to Chaboussou 1987:

..."In vegetal pathology, like in human or animal pathology, an "iatrotogenic disease" is any kind of infection developed by the moderate or abusive use of any drug or aggressive substance. In vegetals, the use of toxic and poisonous substances is the main cause of general plant vulnerability. Frequently, on the other hand, the authors mention the "biologic disequilibrium" coupled to a subtle proliferation of one or other plague just few days after a defensive or a phytosanitary treatment. For example, acaroids infestations can occur after a series of treatments with fungicides as well as insecticides".

After carrying out repercussion analysis on the influence of different agricultural practices such as replenishing of nutrients on plants resistance, Dufrénoy 1936 concluded that: "what actually changes in vegetal cellules is the overall concentration of certain substances. These substances are stored in the form of vacuolar solutions as mineral salts species and/or carboxylic organic acids absorbed from the external environment under a non favorable condition and to be later metabolized by the plant". Dufrénoy defined as "non favorable conditions" the inhibitive effects caused by fertilization disequilibrium due to an excess of macro and micro nutrients such as the classical N, P, K fertilizers and small amounts of elements now considered as activators of enzymatic catalysis.

This plants sensitivity determinism proposed by Dufrénoy 1936 can be restated in other words as "all adverse circumstances that lead to the formation of a new amount of cytoplasm, unpropitious to the growth of vegetal tissues, thus resulting in the accumulation of soluble compounds such as protein fragments (free amino acids) and reductor sugars (monosaccharide species)". The storage of these soluble substances appears to create a favorable atmosphere for the nutrition of parasitic microorganisms and consequently the induced decrease of plant resistance against parasite diseases. In other words, an understanding of the state of proteolysis in vegetal tissues allows us to determine plant sensibility (or vulnerability) to attack by parasite. Nitrogenous organic compounds with high nutritional indices (such as free amino acid and amide) are formed especially on growth ends during senescence period when protein dissociates to amino acids. The statement of proteolyses is predominant over the protein synthesis (Kennedy 1958).

Tomiyama 1963 also points out: “an increase in protein concentration observed in resistant tissues". According to this author, "the accumulation of amide, the increase in protein concentration and phenolic compounds together with an increase in respiration processes strongly all suggest that dislocated materials and their transport are related to the observed increase in the speed of metabolism in vegetal tissues resulting the vegetal showing an increase in resistance against attack by parasites". This entomologic resistance cannot however be attributed to any effects of toxic phenolic compounds, but is derived from the absence of soluble species of nutrients and the ease with which they are assimilated. The absence of soluble species of nutrients in itself results from the stimulation of protein synthesis followed by the production of phenolic material. This line of reasoning appears to fully justify the concept of the Trofobiose Theory which postulates that "all vital processes depend on the satisfaction of the necessities of living organisms, be them vegetals or animals" (Chaboussou 1987).

This statement implies that the extent to which any vegetal, or more precisely, any specific organ of a plant will be attacked by a parasite or disease is determined by its biochemical state which defines the level of satisfaction of the nutritional obligations 
of the attacking parasite or microorganism in question. And this state is not determinate by the nature of the plant alone, but also by the content of soluble nutritional substances. In summary thereof, the preceding statements lead us to conclude that without any intoxication of the plant, the parasite ultimately dies and does so by inanition only. This is experimentally consistent evidence.

\section{CONTROVERSIES}

The above considerations are all relevant when discussing Trofobiose. In fact, almost twenty years after Chaboussou exposed this theme, it is not still easy to scientifically prove or refute the Trofobiose theory. This has been due mainly to limitations of the overall universe since any attempt to prove or refute this theory must be based on real descriptions which must rely on instrumental measurements and analysis of physical, biological or chemical data obtained by using adequate transductions and a variety of signals or by sight and other sensorial organ. Another limitation is the fact that proteins synthesis in living organisms occurs essentially under dynamics conditions and any analysis using vegetal fluids gives only a limited idea of equilibrium under static conditions making any measurements difficult since the flow of nutrients is disrupted on sample collection with the consequent interruption of the plant vital cycle. And this is the main reason for employing indetermination of conceptual order.

One of the major ideas deeply rooted in the Trofobiose Theory (and quite a controversial one) is that this theory postulates an accumulation of free amino acid in cellular vacuoles. However, in his pioneering work, Chaboussou does not explain the tolerance or the acceptable upper limit values of amino acid content. Scheller 1999 later stated that these concentrations cannot be higher than the limit value of $2 \%$. This limit is however observed to be low for practical measurements and hence the determination of protein nitrogen content and free amino acids at this level of concentration is difficult, making it very difficult to evaluate the real conditions of the nutritional equilibrium state. Inversely, it is also difficult to establish a vulnerability' index that measures the likelihood of infestation by disease or plague (insects and acaroids).

Divergences also occur relative to the real nature of enzymatic system of microorganism which takes part in the process of decomposition. Parasites, fungi and also bacteria or virus are designed to attack vegetal tissues only under certain conditions and do not act to destroy healthy tissues since their feeding is restrict to simple (and not complexes) substances. On detecting (by means of any kind of exudates from these fragile tissues) any vulnerable plant tissues, these species attack them and this explains why vegetal tissues are less resistant under proteolysis conditions.

However, microorganisms are discrete in terms of digestive enzymes. Some of them (bacteria) are mono enzymatic; fungi may have two or three digestive enzymes and insects are reported to have a maximal number of twelve enzymes. This is probably the most vulnerability point of the Trofobiose Theory since knowledge of digestive enzymes of discrete microorganisms that take part in the process of decomposition of plants is not well understood. Detailed studies of digestive enzymes of parasites, fungi and also bacteria or virus currently available are not yet precise relative to numbers and in actions, especially in terms of his activation (micro elements).

The most controversial point of the Trofobiose Theory however lies in its essence. It is not clear until now if under conditions of protein synthesis healthy organisms direct their proteins synthesis only to satisfy structural proteins or alimentary proteins, or if the mechanism that controls the phenomena of protein synthesis is driven towards the manufacture of more complexes schema as enzymatic catalysis. The micronutrients of vegetal are supplied through processes of reposition or by the process of active mobilizations. This ionic species act as enzymatic activators and their function on the process of protein synthesis is on enzymes (proteins) with specific goals, as showed in Figure 1. The enzymatic activity occurs inside the cellules cytoplasm, causing freely distributed molecules (A) 
to be orderly orientated (B). The enzymes shown in Figure 1 "are able to find the active sites thus helping free molecules to be correctly position for reaction $(\mathrm{C})$. In this respect, the group formed acts as catalysts joining groups placed in the structure of the proteins (D), acting as enzymes inside cellules (E). The enzymatic action depends on specific activators or micronutrients.

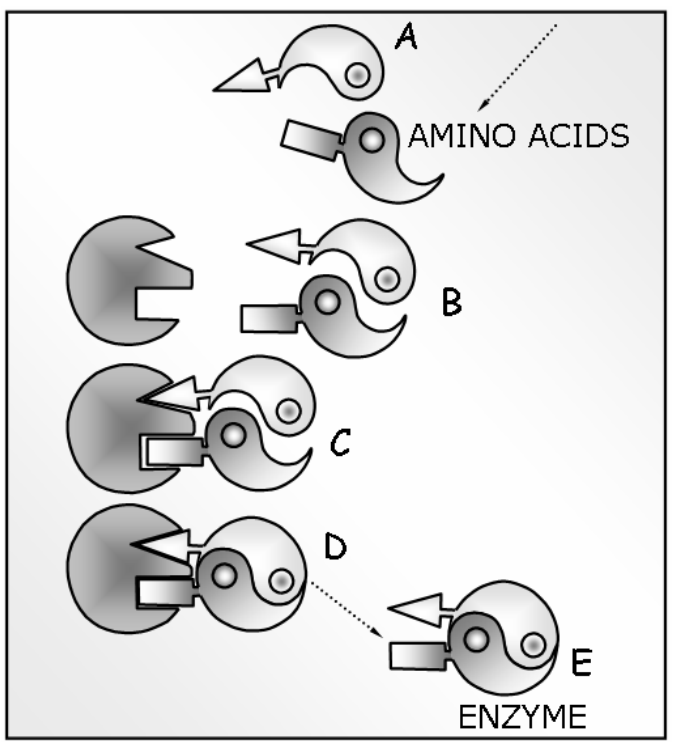

Fig. 1-Enzymatic activities: Biosynthesis of enzymes by effects of micronutrients supply.

The natural resistance of plants is thus highly dependent on proteins which act as enzymes and depends, to lesser extent on others kinds of proteins. In this case the enzymes are the true device to machine tools on cellular activities and plant defenses.

Although many questions and answers exist on food crop production, neither the beauty of the agricultural practice nor the volume of foodstuff produced (even under the most modern practices of genetic engineering) is relevant. This is because these attributes do not confer any nutritional or biological qualities to the resulting foodstuff inasmuch as such quality can only be achieved through the conscientious use of agricultural practices. This makes the theme of food production an inexhaustible one needing a wider discussion.
Figure 2 shows various substances involved in biosynthesis. This representation makes special reference to species which act as natural or intrinsic phyto/ferti protectors of plants.

The major part of these reactions is enzymatic biosynthesis and also includes synthesis of proteins. Many of these substances like polyphenolics (natural flavonoids) are substances that increase the natural resistance or the natural "self defense system" of plants. Systematically, these substances can be detected and quantitatively analyzed in healthy and highly resistant organisms, but some doubts still remain as to whether their synthesis would provide any kind of immunity and if so whether plants can exhibit such protective action when synthesized flavonoids are applied to them.

Figure 2 shows also several cycles of the biosynthesis of various compounds. Based on this figure, one can attempt to explain the protective action of phyto and ferti protectors. This figure also emphasizes some other relevant chemical and biochemical aspects about the trophic (nutritional) action and the action of biotic and abiotic elicitor, especially relative to the use of bio fertilizers, rock powder and the active mobilization of nutrients.

\section{Nutritional Aspects on Diseases MANIFESTATION}

\section{Chemical Fertilization And Products Agriculture}

The technical progresses in food production achieved through Products Agriculture have been made clear in the book by Justus von Liebeg, in 1840: Der Chemie auf Agrikultur und Physiologie (Apud Scheller 2000). During the last 150 years, this approach has always been used only to understand the Rule of Minimum and the Rule of Maximum on vegetal life. This is a complex theme related to many elements and involves the understanding of the role of nitrogen together with other structural elements (carbon, sulfur, oxygen and hydrogen) and the chemical bonds between them on constitutive compounds that insure the existence of vegetal tissues. The best conditions that favor Product Agriculture are represented in Figure 3. 


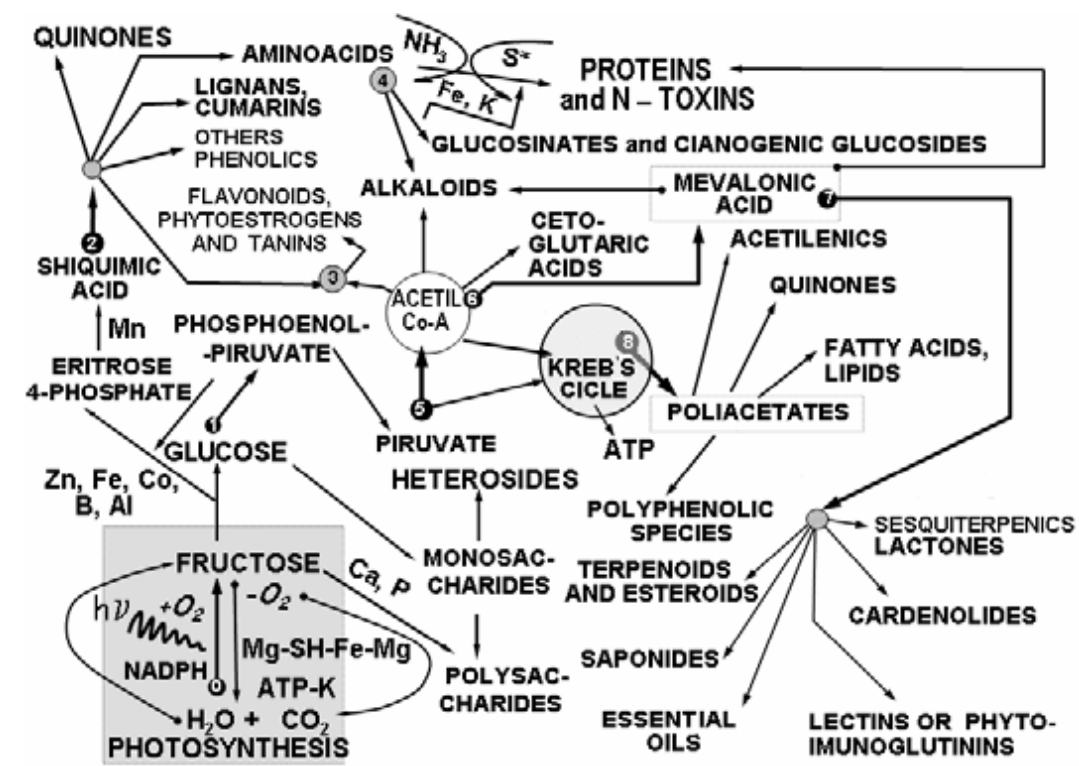

Fig. 2 - Illustration of various nutrients involved in the process of biosynthesis and the participation of micronutrients in abiotic elicitation during the production of Fitoprotector by means of a series of enzymatic reactions.

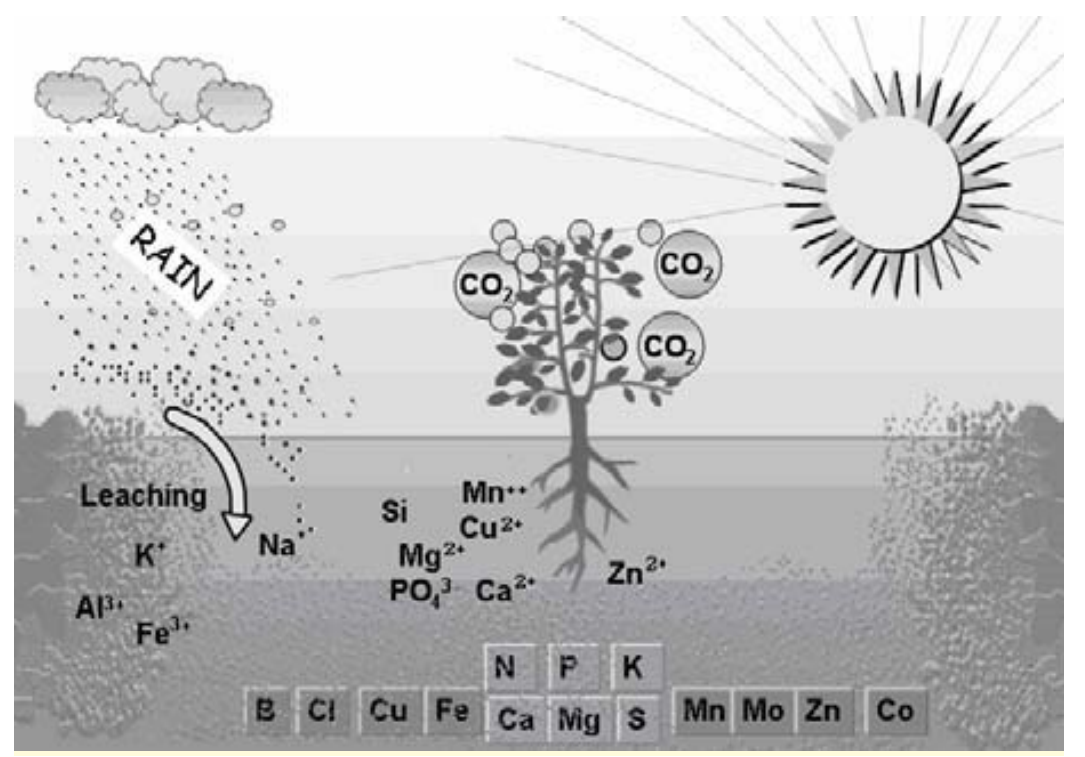

Fig. 3 - Representation of a typical Product Agricultural environment with only chemical intensification during the replenishment of nutrients. 


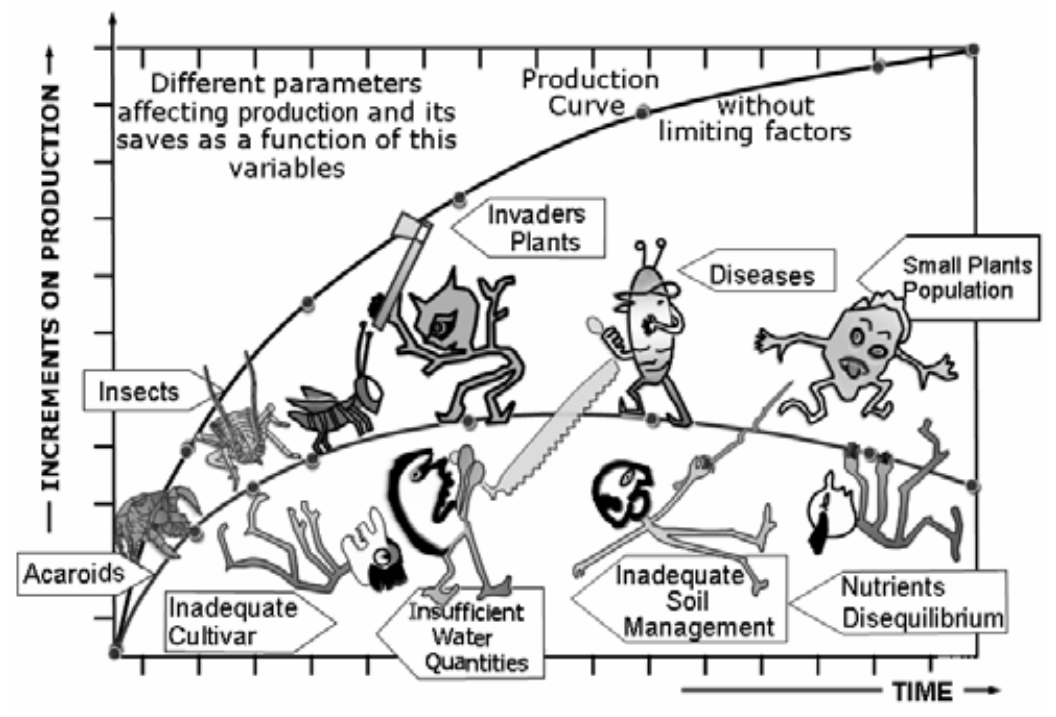

Fig. 4 - Representative figure showing recursive variables and parameters which limit production.

Figure 4, presents limiting parameters for production for all kind of ambient considering changes that may take place on the way of the soil/plant system is treated and variable correlations of these parameters.

The Nutrientional And Agro Ecological POINT OF VIEW

H.P. Rush and H. Müller are considered the pioneers of Biological Organic Agriculture and the basic concepts that guide the production of organic and biodynamic food crops (Scheller 2000) were first formulated by them. Scheller 2000 also mentions Rush's book on Soil Fertility ("Bodenfrucht Barkeit") as a major contribution in the field of organic and biodynamic agriculture. Nonetheless, Hans Müller was the first to apply the theoretical ideas of Rudolph Steiner (firstly published in 1924, Apud Scheller 2000), who is considered the real mentor of biodynamic and organic agricultural practices. To understand the role that nutrients play on Organic and Biodynamic Agriculture, it becomes recommendable to consider sulfur as key element and try to understand the role of this element when it combines with others constitutive elements such as carbon, nitrogen, oxygen and hydrogen. More es- pecially, the importance and role of primary chemical bonds and secondary bonds on constitutive compounds like proteins (meaning tertiary structures) have to be addressed. In fact, this line of approach is much more satisfactory in explaining various concepts in organic and biodynamic agricultures than any other approach based on nitrogen as key element.

The mechanics and mechanisms of the supply of nutrients are also a controversial issue in organic and biodynamic agricultures. To understand this phenomenon, the following basic aspects must be considered:

- Plants do not need only absorb dissolved soils nutrients following previous nutritional cycles, but they must also do tedious biological and functional work to make possible the use of fixed soils nutrients.

- By means of external mechanisms, plants choose their nutrients by using vital and completely highly organized processes following natural determinism. Without these mechanisms which lead to plasma maturity, plants do not develop. This plant development can be measured by observing the microbial popula- 
tion of the rizosphere (microbial flora) which rises proportionately to the plant's capability in synthesizing nutrients, or when the vegetal is able to transport light to chlorophyll carriers, thus "maintaining itself green in color".

Rush and Müller suggested that, "there is a great amount of nutrient stored in the form of strongly fixed low solubility minerals which plants are unable to get by mean of dissolution and hence plants try to dissolve these fixed nutrients by using rizosphere exudates". In order to understand these phenomena of plant intake of nutrient through rizosphere exudates, other basic aspects must come into play. These include the fact that:

- Plants use some assimilated nutrients (by their trophic selection and modifications) to carry exudates into the soil using special kinds of transport mechanisms by diffusion against the ascendant flow of xylem. Plants do this because the exudates help in creating a symbiotic microorganism flora in the rizosphere, the biological intensifications ending up as benefits to vegetal life.

- Among various types of bacteria present in the soil, plants always prefer a certain kind. The choice is done as a function of nutrients selection taken on the basis of symbiosis, and plant give preferences to non alkalinizing lactic acid formers. This phenomenon can also be proven by observing the population growth of the rizosphere flora which is expected to increase proportionately to the ability and capacity of plants to synthesize their selected nutrients and, as mentioned above, to the ability of the vegetal to transport light chlorophyll carriers or in other words, the ability to "stay green in color".

In conclusion thereof, the supplies of inorganic synthetic and soluble nitrogen are the major causes of nutritional disequilibrium and food quality degradation. Hence, any replenishment of soil nutrients must be done in such a way that plants interact with soil microorganisms. Figure 5 explains such an interaction.
Following the ideas of Rush and Müller, "plant and the soil microorganisms must transform the nutrients supplied to be absorbed and assimilated".

So, at least few soluble soil minerals must be considered as major sources of nutrients in the production of foodstuff and in extreme cases of real necessity, rocks powder can be applied in quantities equivalent to the needs for reposition". It is thus worth stating that:

- Under conditions of severe necessity of potash (exhausted and poor soils), farmers are recommended to use $\mathrm{K}_{2} \mathrm{SO}_{4}$ while in severe cases of phosphorus necessity, the recommendable choice is the use of rock powder.

- These resources should not, however, be considered as "replenishment of nutrients", but only as an extra input in extreme cases of long term failure of the process of biological mobilization of nutrients.

- Fertilizers derived from inorganic synthetic and soluble nitrogen are not recommended. Under Agro-ecological practices, farmers are advised to take maximum advantage of stored nutrients deposited in the soil and hence any other non-renewable resources must be considered only in conditions of emergency.

DifFERENCES BETWEen ProduCT-BASED Agricultural Practices ANd ORganic AND BIODYNAMIC AgRicUlture BASED ON Nutritional APPROACHES

During the 1980s and 90s, the difference between Product Agriculture and Organic and Biodynamic Agricultures with respect to representation of fertilization and the supply of nutrients ended up in nothing. The major reason for lack of consensus on the subject laid in the principle of soil replenishment by fertilizers. The existence of very little or no knowledge on the subject generated doubts on the future of soils especially if the productivity of cultivatable soil would diminish. It has however been proven recently that the soil nutrients known to have very low solubility and therefore not being 


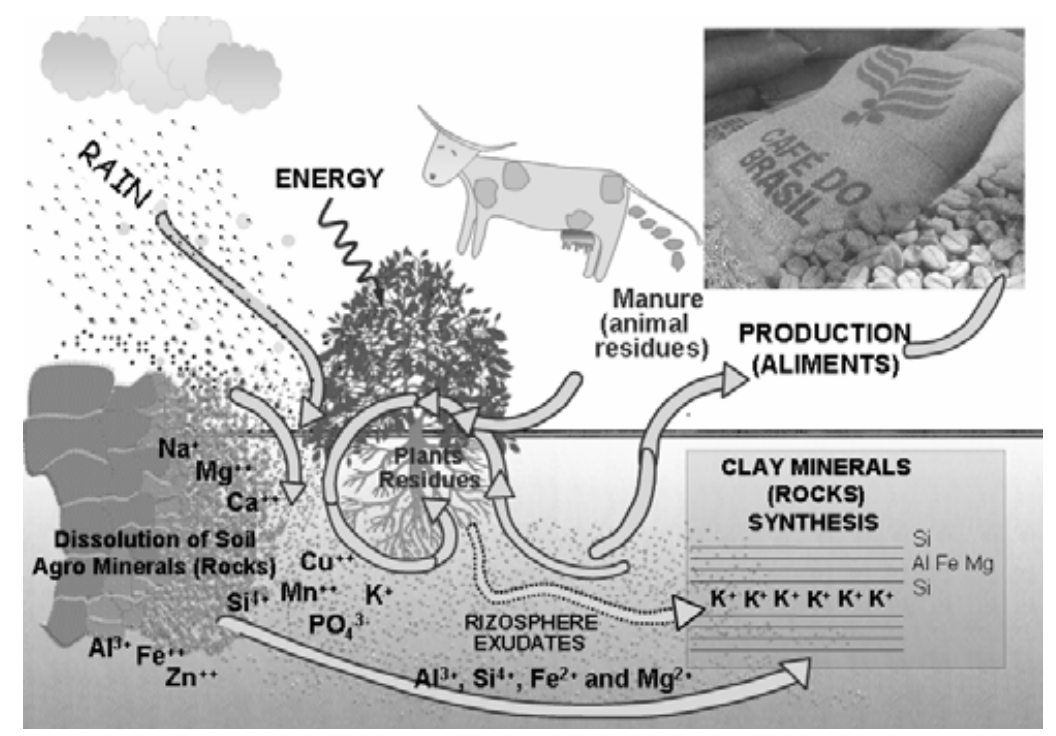

Fig. 5 - Representation of a typical Agro Ecological Agricultural environment with biological intensification on replenishment of soil fertility and the action of exudates on active mobilization and dissolution of nutrients from low solubility agrominerals.

used by plants can also be mobilized and used by plants to satisfy their necessities.

Following ideas of Prof. Dr. Edwin Scheller 2000 , many of the relevant and controversial questions on the topic were answered by the development of knowledge in the domain of plant nutrition and the phenomenon of Product Agricultural practices. The answers to major doubts are related to the active mobilization of nutrients, as follows:

1. With increasing productivity, different kinds of cultures become independents of the supply of phosphorus and potassium.

2. The active mobilization of nutrients is now an unquestionable scientific fact that can be proven and implemented.

3. An increase in the rate of productivity results in an increase in the rates of substance mobilization and energy from the rizosphere.

4. Nitrogen has an important role on the active mobilization of nutrients and hence any increase in quality of food production depends on the source of nitrogen supply.
5. The fact that nitrogen supplies are stored in nitrogen compounds in humus substances strongly suggests that humus remains the principal source of the supply of nitrogen in the vegetal kingdom.

6. The intensity of food cultivation exerts marked influences on the replenishment of nitrogen from humus: the more intense and consortiated is the cultivation with biomass, the better the productivity. Hence, if better conditions of production of biomass are assured (nutrition or fertilization of biomass), the resulting quality of food is better. Figure 6 shows a typical process agricultural environment illustrating this comment.

7. Humus substances are universal compounds in the soil. Their composition in terms of proteins and poly electrolytic structures are a fundamental issue. The replenishment of Humus depends on the quantity of nutrients in the soil feed with appropriated and stabilized organic inputs including manures and plant and tree pruning and leguminous mulches. 


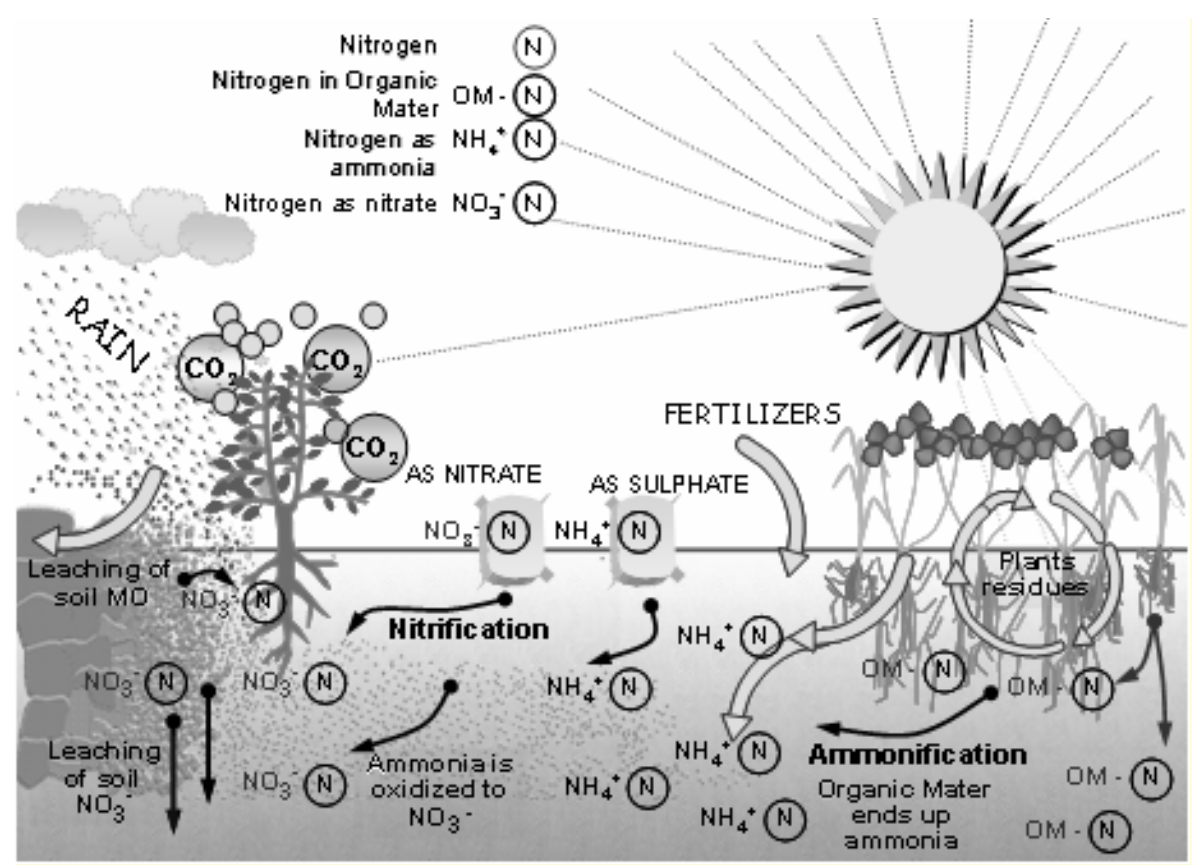

Fig. 6 - Representation of a typical of Process Agricultural environment with chemical and biologic intensification during the replenishment of soil fertility.

\section{ACTIVE Dissolution AND MobILIZATION OF} NUTRIENTS AND SOIL ACIDITY

The term "Active Mobilization of Nutrients" by means of dissolution of low solubility rock powder involves advanced nutritional considerations and in itself needs a separate approach based on a consistent and broader attention. Soil agrominerals occur naturally in concentrations and forms that can be used as alternative fertilizers or amendments to replenish soil fertility. This is quiet interesting since farmers, instead of spending their saving on expensive and mainly using imported and water-soluble fertilizers, they could resort to alternative ways of accessing vital plants nutrients resources (van Straaten 2002).

Agrominerals include mainly limestone and dolomite, and also various soils made up of silicate rocks. The best agrominerals are: naturally occurring nitrate minerals in sizable deposits (saltpeter), phosphate rocks such as apatite compounds with P- and N- bearing complexes (Guano Miner- als), Sylvite $(\mathrm{KCl})$ and K-bearing salt complexes, K- Silicates such as K- Mica, glauconites and Kbearing volcanic rocks, sulfur, sulfides such as Pyrite and sulfates - Gypsum, Calcium and Magnesium Carbonates and various silicate minerals and rocks used to conserve nutrients (Zeolite) and soil moisture (van Straaten 2002). The decomposition of these agrominerals is a technologically complex process that has to be kept at appropriate levels in agricultural management adapted to a specific environment and climate. Rates of nutrients release, recovery cycles and replenishments are complicated by the fact that chemical weathering, dissolution and the release of nutrients from mineral are not fast processes. Based on this, adequate precautions must be taken to correct any imbalances between soil export and soil import, even if this is complex, since this is necessary to replenish nutrients that must have been removed or lost. To perfectly understand this process, it is necessary to detail the quantities and flow of nutrients, quantity and quality of row materials (rocks), precipitation, kind of 


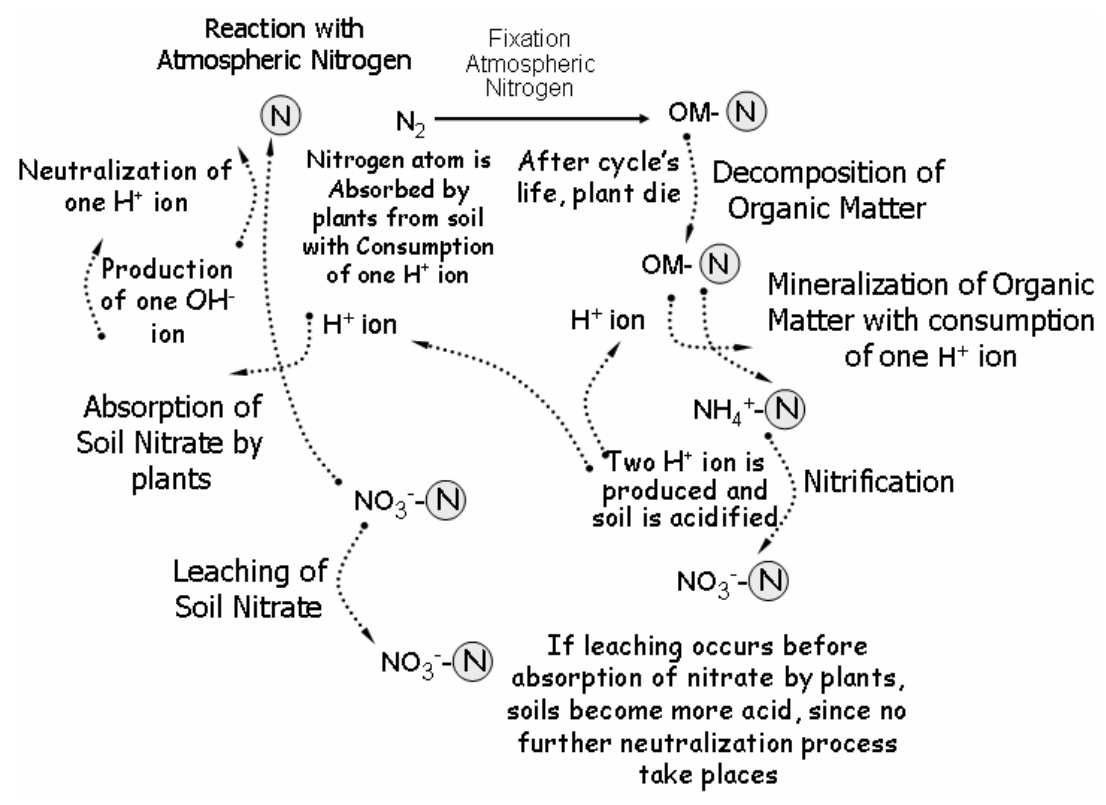

Fig. 7 - A schematic representation of the Nitrogen cycle showing the reactions which occur due to an increase in $\mathrm{H}^{+}$ions concentration in the soil.

plants, and how the biological diversity and plant, tree pruning and leguminous mulches will be used on the cultivable soil as well as organic inputs including manures and the rizosphere exudates and its action on the active dissolution of nutrients from low soluble rocks. Since agrominerals do not occur in a form that is directly available to plants, but must be modified physically, chemically and biologically to become effective nutrients for the soil and plants, in order to apply fertilization by means of rock powder and organic material, one needs to know the possibilities of any leaching of organic material and any transformations that can take place in organic material (manures, plant and tree pruning and leguminous mulches). This is of very fundamental importance since the result of such transformations is the necessary nitrogen supplied in the form of nitrates or as ammonia salts to plant on rizosphere.

It is necessary to observe that the conditions for production in organic and biodynamic agricultural environments are more favorable than those in environments where replenishment of nutrients is carried out. However, this is only true if any phe- nomenon that promotes rock dissolution specially powders containing low solubility species such as Mn (IV) and other low solubility materials in soils by mean of reactions which occur when ammonia is absorbed in rizosphere (acid process of exudation) is guaranteed as shown in Figure 5. The understanding of these phenomena together with soil acidity makes it a necessary requisite in understanding the nitrogen cycle shown in Figure 7, and the state of acidity equilibrium in soil solutions (system containing aluminum silicates $/ \mathrm{CaCO}_{3(s)} / \mathrm{CO}_{2(g)} /$ $\mathrm{H}_{2} \mathrm{O}$ ), and containing $\mathrm{CO}_{2}$ under different partial pressures and leaching and buffer effects which takes place (Figure 8) and the mobilization of aluminum in soil as a function of soil acidity as well as the effect of acidity and alkalinity on the leaching of nitrate ions, as showed in Figure 9 and complemented by Figure 10. The continuous use of soil nutrients in Product Agriculture requires continuous replenishing of these nutrients. The result is that soil is "mined" and this process increases soil acidity. This increase in acidity is due to successive carbon and nitrogen cycles. 
The primary causes of acidity of soils that must be taken into account when considering the soil-plant-microbial flora system are: (1) $\mathrm{Ni}$ trification; (2) Dissociation of Organic Acids from plants, tree pruning - the only organic input or organic material (OM) by action of microorganisms (microflora) or leaching of likens; (3) Immobilization or volatilization of soil $\mathrm{NH}_{3}$; (4) Exudation of $\mathrm{H}^{+}$ions by roots as a consequence of the assimilation of more cationic species than anionic ones by the rizosphere.

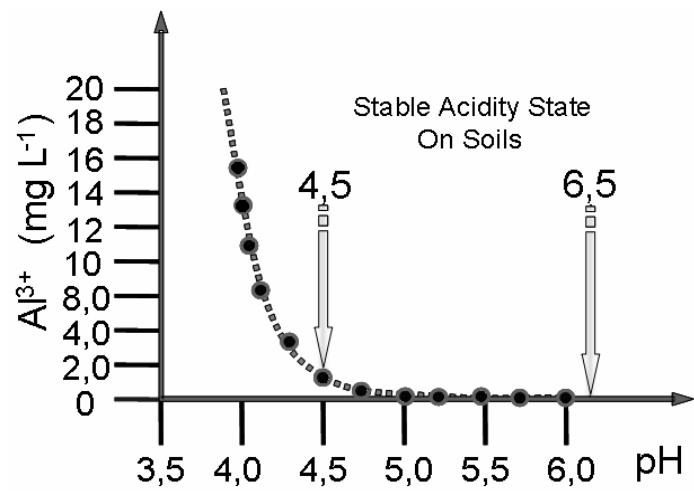

Fig. 8 - The mobilization and dissolution of aluminum from soils due to an increase in acidity induced by successive nitrogen cycles.

The active mobilization of nutrients and the supply of manure as a source of organic material result in nitrogen which compensates for any increase in acidity from organic acids and nitrate ions. This process called soil alkalinization is illustrated in Figure 9 and 10 and shows the following aspects:

1. Denitrification by means of the decomposition of $\mathrm{NO}_{3}$ - by soil microflora,

2. Mineralization of nitrogen from organic material, $\mathrm{OM}$ in the soil.

3. Absorption of $\mathrm{H}^{+}$ions from more acid soil' OM by inorganic anions from less acid soil' OM,

4. Oxidation of organic anions to $\mathrm{CO}_{2}$ and water,

5. Exudation of $\mathrm{HCO}_{3^{-}}$or $\mathrm{OH}^{-}$in response to the assimilation of more anions than cations,
6. Control of the leaching of $\mathrm{OM}$ and $\mathrm{NO}_{3}-$ with better conditions of the stratification of soil structure without any large acid layer and no compact structure on the surface resulting from inputs of leguminous mulches and plant and tree pruning from biological degradation and assimilation by plants.

When plants that fix nitrogen (gramineae and leguminous) are cut, vegetal biomass can be formed by means of environmental and climatic action thus releasing soil Organic Material (OM) that is mineralized to give $\mathrm{NO}_{3-}$ or $\mathrm{NH}_{4}^{+}$. To explain this phenomenon, the following aspects must be considered:

(1) The overall OM in the soil ends up as organic soil mass content of about $2.0 \%$ (in OM),

(2) From the decomposition of soil OM $90 \%$ of nitrogen replenished is obtained,

(3) The soil OM has $5.0 \%$ nitrogen in mass,

(4) $1.0 \%$ of which gives 10 to $14 \mathrm{~kg}$ of nitrogen per year.

On the question of the decomposition of soil OM, proteins and others nitrogen compounds present in the soil are converted to ammonium as shown in reaction (1) (ammonification). Subsequently, the ammonium formed suffers a bacteriological conversion to give the nitrate ions (nitrification) as shown in reaction (2).

$$
\begin{gathered}
\text { MO of soil } \rightarrow \mathrm{NH}_{4}^{+} \\
\mathrm{NH}_{4(a q)}^{+}+2 \mathrm{O}_{2(g)} \rightarrow \mathrm{NO}_{3(a q)}^{-} \\
+2 \mathrm{H}_{(a q)}^{+}+\mathrm{H}_{2} \mathrm{O}_{(l)}
\end{gathered}
$$

This last reaction depends on the presence of $\mathrm{O}_{2}$ in the soil and can be inhibited by gramineae or synthetic materials such as carboxy-methyl pyrazol (in E.U.A.).

Nitrate ions can be lost by leaching causing disequilibrium in acidity (increase of $\mathrm{H}^{+}$in soils). To explain the nitrate lost, three important sources of disequilibrium must be considered.

1. Denitrification of $\mathrm{NO}_{3^{-}}$: Action of denitrification bacteria presents in the soil:

$$
\mathrm{NO}_{3^{-}} \rightarrow \mathrm{O}_{2}+\mathrm{N}_{2} \mathrm{O} \quad \text { e, }
$$




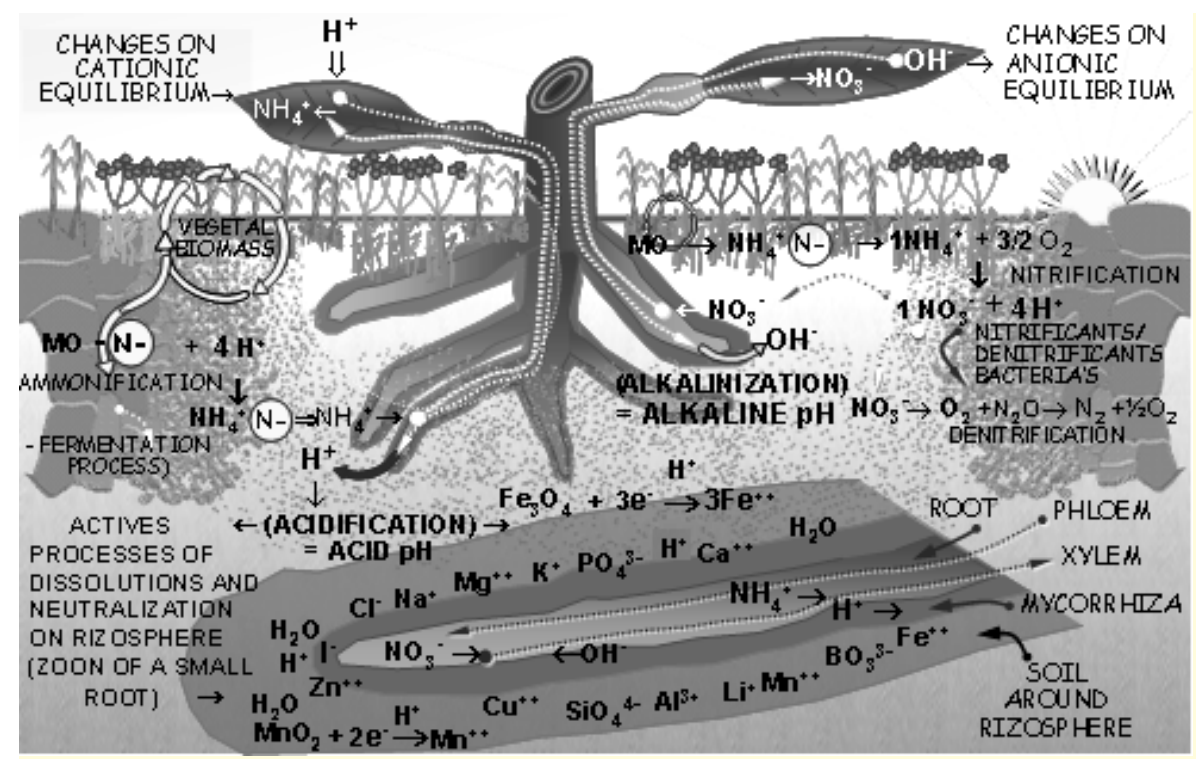

Fig. 9 - The Nitrogen cycle in the soil showing ammonification, nitrification and acidity at rizosphere resulting from an increase in $\mathrm{H}^{+}$which helps in the active dissolution of nutrients.

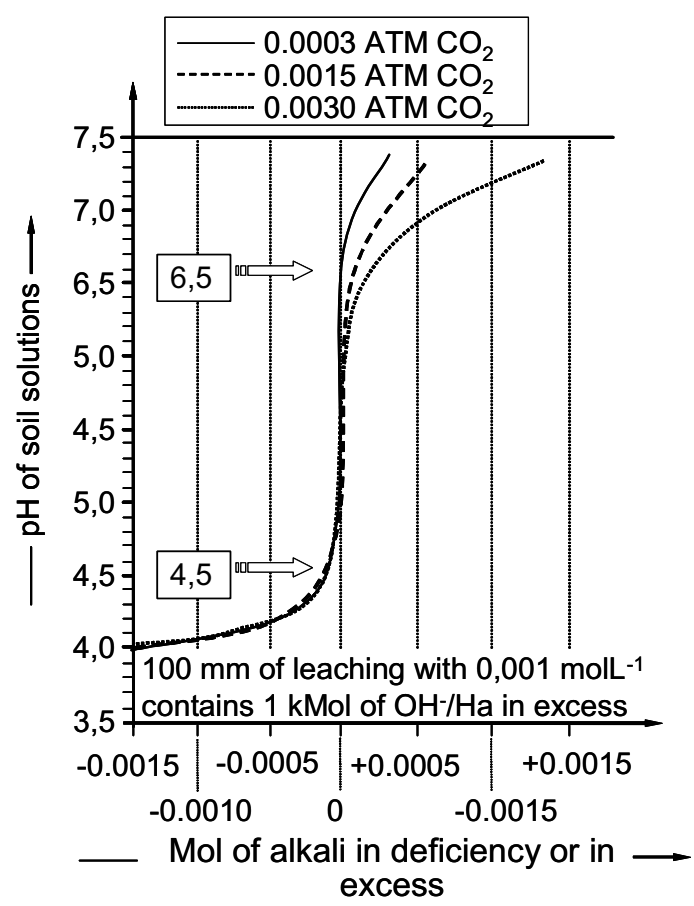

Fig. 10 - Control of soil acidity illustrating the buffer effects in soil: illustration of the system $\mathrm{HCO}_{3^{-}} / \mathrm{H}_{2} \mathrm{CO}_{3}\left(\mathrm{CO}_{2}\right.$ aqueous $)$. 


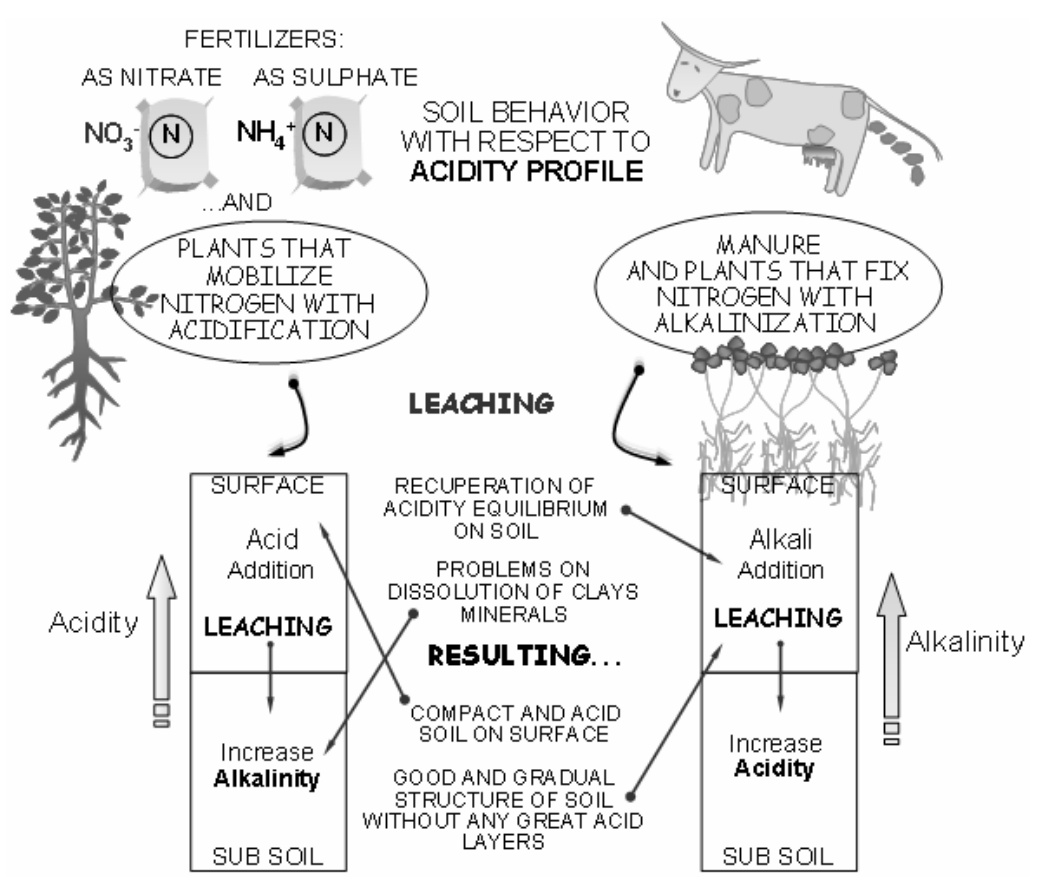

Fig. 11 - Effects of leaching on soils.

$$
\mathrm{N}_{2} \mathrm{O} \rightarrow \mathrm{N}_{2}+\frac{1}{2} \mathrm{O}_{2}
$$

(Lost of gas to atmosphere)

2. Absorption by clay minerals,

3. Leaching.

The overall effects of leaching as well as other aspects affecting conditions of acidity and association of culture with biomass are showed on Figure 11.

\section{CONCLUSION}

Linking the exposed relevant concepts about the use of some ecological practices to food production with special reference to Trofobiose Theory helps us understand the principle of Active Dissolution of Rocks as an important tool to improve sustainability of Organic, Biodynamic and Process Agricultures. This effectively can help in our understanding sustainable agriculture. The future well being of the world's population depends on linking the food challenges we face today to sustainable devel- opment, food security and access to sufficient food by all.

\section{RESUMO}

O objetivo principal deste trabalho é estabelecer relação entre alguns conceitos relevantes sobre o uso de práticas agro-ecológicas na produção de alimentos. Em um tópico especial, a Teoria da Trofobiose bem como os princípios da Dissolução Ativa de Rochas são considerados como importantes ferramentas na implementação da sustentabilidade no processo de Agriculturas Orgânica e Biodinâmica.

Palavras-chave: sustentabilidade, trofobiose, nutrição vegetal, equilíbrio nutricional, agro-ecologia, pós-derocha, fertilização mineral, fertilização orgânica.

\section{REFERENCES}

Chaboussou F. 1987. Plantas Doentes pelo uso de Agrotóxicos. L \& PM Editores S/A, Porto Alegre, RS, Brasil, 253 p.

DUFRÉNOY J. 1936. Le traitement du sol, désinfection, amendement, fumure, en vue de combattre chez 
les plantes agricoles de grande culture les affections parasitaires et les maladies de carence. Ann Agron Suisse, p. 680-728.

KEnNEDY JS. 1958. Physiological conditions of the host plant and susceptibility to aphid attack. Entomol Exp Applic 1: 50-65.

Scarpari LM, Methardt LW, Pomela AW, Schivianato MA, Mazzafera P, CASCARdo JM AND PEREIRA GAG. 2005. Biochemical change during the development of wiches' broom: the most important disease of cocoa in Brazil caused by Crinipellis perniciosa. J Exp Botany 56 (413): 865-867.

SCHELLER E. 1999. Wissenschaftilche Grundlagen der Pflanzenernährrung in ökologischen Landbau. Ciclo de palestras sobre nutrição avançada de plantas e vivicação do solo, IBD, Casa Some, Botucatu, SP, Brasil.
SCHELler E. 2000. Fundamentos Científicos da Nutrição Vegetal na Agricultura Ecológica (ABD). Editora Agroecológica, Campinas, SP, Brasil, 354 p.

SteINER R. 1993. Fundamentos da Agricultura Biodinâmica. Editora Antroposófica, São Paulo, SP, Brasil, 235 p.

TOMiYma K. 1963. Physiology and biochemistry of diseases resistance of Plants. Ann Rev Phytopathm 1: 295.

VAN STRAATEN P. 2002. Rocks for Crops.: agrominerals of Sub-Saharan Africa. ICRAG, Nairobi, Kenya, Africa, 338 p. ISBN 0-88955-512-5. 